\title{
PENGELOLAAN INTERAKSI KUALITAS PROSES BELAJAR MENGAJAR TERHADAP PENGEMBANGAN DIRI ANAK DALAM KONTEKS MINAT BELAJAR
}

\author{
Belinda Mau*1, Areyne Christi ${ }^{2}$ \\ ${ }^{1,2}$ Sekolah Tinggi Excelsius Surabaya \\ *belindamau0@gmail.com
}

\begin{abstract}
In this era of globalization, teachers are very dominant in self-actualizing to educate the nation in facing the challenges and competition in the world, so that they are required to improve their professionalism in dealing with any existing problems. Solutions to answer the problems faced by teachers arise in the following questions: Who is the teacher? What is the role of the teacher both as a teacher and in relation to their students? How to manage the quality of the teaching and learning process on children's self-development in the context of interest in learning? The answers are: (1) a teacher is a professional educator who educates, teaches a science, guides, trains, provides assessments, and evaluates students. (2) the role of the teacher to work holistically. The teacher not only carries out his duties as a teacher, but becomes an example and a companion to his students. (3) the teacher must be able to manage the class very well so that in every learning process, children can be interested and respond when a teacher delivers a material
\end{abstract}

\section{Keywords: Teachers, Students, The Quality Of The Teaching-Learning Process}

Abstrak: Dalam era globalisasi ini guru sangatlah dominan di dalam mengaktualisasi diri untuk mencerdaskan bangsa dalam menghadapi tantangan dan persaingan dunia, sehingga dituntut untuk meningkatkan profesionalnya dalam menangani setiap masalah yang ada. Solusi untuk menjawab persoalan-persoalan yang di hadapi oleh guru muncul dalam pertanyaan sebagai berikut: Siapakah guru itu? Apakah peranan guru baik sebagai guru dan berhubungan dengan anak didiknya? Bagaimanakah mengelola kualitas proses belajar mengajar terhadap pengembangan diri anak dalam konteks minat belajar? Jawabnya adalah: (1) guru adalah seorang tenaga pendidik profesional yang mendidik, mengajarkan suatu ilmu, membimbing, melatih, memberikan penilaian, serta melakukan evaluasi kepada peserta didik. (2) peranan guru bekerja secara holistik. Guru tidak saja menjalankan tugasnya sebagai seorang pengajar, tetapi menjadi teladan dan teman bergaul bagi para muridnya. (3) guru harus dapat mengelola kelas dengan sangat baik sehingga dalam setiap proses pembelajaran, anak dapat tertarik dan meresponi ketika seorang guru menyampaikan sebuah materi

Kata Kunci: Guru, Anak Didik, Kualitas Proses Belajar-Mengajar 


\section{PENDAHULUAN}

Pendidikan merupakan salah satu agenda pemerintah yang dilaksanakan secara kontinyu. Agenda ini dititik beratkan pada penggunaan sumber daya manusia, karena sumber daya manusia merupakan kunci keberhasilan pembangunan bangsa. Usaha meningkatkan sumber daya manusia ini dapat dilihat dari keinginan pemerintah memperbaiki dan memenuhi perangkat dalam komponen yang berkaitan dengan lembaga pendidikan, salah satunya adalah guru. Suatu pendidikan dapat dikatakan berhasil atau tinggi mutunya apabila pengetahuan, sikap dan keterampilan yang dimiliki oleh para guru berguna bagi perkembangan Pendidikan selanjutnya.

Upaya peningkatan kualitas pendidikan merupakan salah satu pokok permasalahan. Ada beberapa pendapat mengenai proses belajar mengajar. Usman mengatakan bahwa proses belajar mengajar adalah suatu proses yang berlangsung dalam situasi edukatif untuk mencapai tujuan tertentu. Dalam proses belajar mengajar ada guru, siswa dan sesuatu yang diajarkan. ${ }^{1}$ William Burton mengatakan bahwa proses belajar ialah pengalaman, berbuat, mereaksi, dan melampaui (Under Going). ${ }^{2}$

Dalam era globalisasi ini guru sangatlah dominan di dalam mengaktualisasi diri untuk mencerdaskan bangsa dalam menghadapi tantangan dan persaingan dunia, sehingga dituntut untuk meningkatkan profesionalnya dalam menangani setiap masalah yang ada. Tetapi kenyataan sekarang menunjukkan bahwa masih rendahnya kualitas guru yang berakibat pada mutu lulusan yang masih dipertanyakan.

Demikian juga dalam melaksanakan tugasnya guru masih dihadapi berbagai permasalahan baik secara kuantitatif maupun kualitatif. Seperti yang dikatakan Akadum bahwa dunia guru masih terlilit dua masalah yang memiliki mutual korelasi yang pemecahannya memerlukan kearifan dan

${ }^{1}$ Ahmad Usman, Studi Pengembangan Metode

Pendidikan Professional Tenaga Kependidikan (Bandung: IKIP, 2000), 59.

${ }^{2}$ Oemar Hamalik, Proses Belajar Mengajar

(Jakarta: PT. Bumi Aksara, 2003), 31.

${ }^{3}$ Akadum, "Potret Guru Memasuki Milenium 42 | Vol. 2 No. 2 (Juli-Desember 2018) kebijaksanaan beberapa pihak terutama pengambil kebijakan. ${ }^{3}$

Sebagian dari Proses pembelajaran atau proses belajar mengajar merupakan suatu proses yang mengandung serangkaian perbuatan guru dan siswa atas dasar hubungan timbal balik yang berlangsung dalam situasi edukatif untuk mencapai tujuan tertentu. Interaksi antara guru dengan siswa itu merupakan syarat utama bagi berlangsungnya proses belajar mengajar. Interaksi dalam proses belajar mengajar mempunyai arti yang lebih luas, tidak sekedar hubungan antara guru dengan siswa, tetapi berupa interaksi edukatif, yaitu bukan hanya penyampaian pesan berupa pengetahuan, melainkan juga penanaman sikap dan nilai-nilai pada diri siswa yang sedang belajar. Lebih dari itu peranan guru dalam proses belajar mengajar seperti yang diungkapkan Wrightman yaitu serangkaian tingkah laku yang saling berkaitan yang dilakukan dalam suatu situasi tertentu serta berhubungan dengan kemajuan perubahan tingkah laku dan perkembangan siswa yang menjadi tujuannya. ${ }^{4}$

Kemudian proses pembelajaran merupakan sebagai inti dari proses pendidikan secara keseluruhan, sebagaimana guru adalah pemegang peran utama dalam proses mengajar anak didik. Peristiwa pembelajaran banyak berakar pada berbagai pandangan dan konsep. Oleh karena itu, perwujudan pembelajaran dapat terjadi dalam berbagai model. Berkaitan hal tersebut, Bruce dan Marshal Weil mengemukakan 22 model mengajar yang dikelompokkan ke dalam 4 hal, yaitu: (1) proses informasi, (2) perkembangan pribadi, (3) interaksi sosial, dan (4) modifikasi tingkah laku. $^{5}$

Persoalan yang muncul adalah, guruguru di sekolah banyak yang "gagap" dan mengalami kesulitan ketika diminta menyusun bahan ajar sendiri, dan lebih banyak yang menggunakan bahan ajar buatan orang lain ataupun bikinan pabrik pada kegiatan

Ketiga. Suara Pembaharuan”, http://www.suarapembaharuan.com/News/1999/01/220 199/ OpEd (Diakses 7 Juni 2008), 1-2.

${ }^{4}$ Moh. Uzer Usman, Menjadi Guru Profesional (Bandung: Remaja Rosdakarya, 2005), 17. ${ }^{5}$ Ibid. 
pembelajaran yang mereka lakukan. ${ }^{6} \mathrm{Hal}$ ini selaras dengan pendapat Daryanto mengatakan bahwa walaupun mereka tahu dan sadar bahwa bahan ajar yang mereka gunakan seringkali tidak sesuai dengan konteks dan situasi sosial budaya peserta didik. ${ }^{7}$ Hal ini merupakan sebuah fenomena yang sungguh menyedihkan dan memprihatinkan bagi dunia pendidikan di Indonesia. Bahan ajar merupakan salah satu faktor penting dalam keefektifan sebuah pembelajaran. Kurangnya bahan ajar tentunya dapat memengaruhi kualitas pembelajaran anak. $^{8}$

Banyak guru yang hilang arah atau bingung di tengah tengah proses pembelajaran hanya karena tidak memiliki perangkat pembelajaran. Perangkat pembelajaran memberi panduan apa yang harus dilakukan seorang guru di dalam kelas dan memberi panduan dalam mengembangkan teknik mengajar dan memberi panduan untuk merancang perangkat yang lebih baik. ${ }^{9}$ Tetapi pengembangan diri di sekolah ternyata belum dapat dilaksanakan, pada dasarnya guru belum memahami tentang pengembangan diri, apakah bentuk mata pelajaran, siapa yang berhak mengajarkannya, dan lain sebagainya. Padahal keberadaan pengembangan diri bagi anak SD sangat diperlukan, yaitu untuk mengembangkan semua potensi yang dimiliki oleh anak.

Masalah guru adalah para guru tidak sepenuhnya melaksanakan kompenenkompenen pengeloaan di dalam kelas seperti: (1) Perangkat pembelajaran, (2) kurang kreatif dalam mengajar, (3) guru tidak memiliki efisiensi dalam mengajar sehingga guru tersebut mengajar dengan menggunakan nada yang sangat keras dan kasar itu bisa menghabat pengembanagan diri anak, dan (3) guru kurang memperhatikan anak-anak didiknya sehingga tidak dapat melihat kemampuan serta pontesi

\footnotetext{
${ }^{6}$ Moh. Sholeh Hamid, Metode Edutainment (Jogjakarta: DIVA Press, 2011), 45.

${ }^{7}$ Daryanto \& Mulyo Rahardjo, Model Pembelajaran Inovatif (Yogyakarta: Gava Media, 2012), 18.

${ }^{8}$ Depdiknas, Kamus Besar Bahasa Indonesia (Jakarta: Balai Pustaka, 2005), 3.

${ }^{9}$ Trianto, Model Pembelajaran Terpadu, Konsep, Strategi dan. Implementasinya dalam KTSP (Jakarta: Bumi Aksara, 2010), 9.
}

terhadap diri anak.

Solusi untuk menjawab persoalanpersoalan yang di hadapi oleh guru muncul dalam pertanyaan sebagai berikut: Siapakah guru itu? Apakah peranan guru baik sebagai guru dan berhubungan dengan anak didiknya? Bagaimanakah mengelola kualitas proses belajar mengajar terhadap pengembangan diri anak dalam konteks minat belajar?

\section{PEMBAHASAN}

\section{Pengertian tentang Guru}

Kata "guru" berarti orang yang pekerjaan, mata pencaharian, atau profesinya mengajar. ${ }^{10}$ Guru berasal dari bahasa Sansekerta yang artinya berat, besar, penting, baik sekali, terhormat, dan pengajar. Guru dalam bahasa Inggris "teacher" yang berarti guru atau pengajar, "educator" berarti pendidik atau ahli mendidik, dan tutor berarti guru pribadi, guru yang mengajar di rumah, atau guru yang memberi les. ${ }^{11}$ Dengan demikian bahwa guru adalah pendidik dan pengajar pada pendidikan anak usia dini jalur sekolah atau pendidikan formal, pendidikan dasar, dan pendidikan menengah.

Undang-Undang Republik Indonesia Nomor 14 Tahun 2005 tentang Guru dan Dosen, mengatakan bahwa guru adalah pendidik profesional dengan tugas utama mendidik, mengajar, membimbing, mengarahkan, melatih, menilai, dan mengevaluasi peserta didik pada pendidikan usia dini, pendidikan dasar, dan pendidikan menengah jalur pendidikan formal. ${ }^{12}$ Berkaitan hal ini, maka Atmaka mengatakan bahwa pendidik atau guru adalah orang yang bertanggung jawab untuk memberikan. ${ }^{13}$ Sedangkan Usman mengatakan bahwa guru

\footnotetext{
10"Guru", KBBI. Offline. Versi 15.1.

${ }^{11}$ Sri Minarti, Ilmu Pendidikan Islam: Fakta Teoritis-Filosofis dan Aplikatif-Normatif (Jakarta: Amzah, 2013), 107-108.

${ }^{12}$ Supardi, Kinerja Guru (Jakarta: PT Raja Grafindo Persada, 2014), 8.

${ }^{13}$ Dri Atmaka,Tips Menjadi Guru Kreatif (Bandung: Krama Widya, 2004), 17.
}

Excelsis Deo: Jurnal Teologi, Misiologi, dan Pendidikan | 43 
adalah setiap orang yang berwenang dan bertugas dalam dunia pendidikan dan pengajaran pada lembaga pendidikan formal. ${ }^{14}$

Guru berarti orang yang mampu menyelesaikan hidup dalam segala dimensi, tetapi tetap saja guru mempunyai ramburambu. Guru mesti taat akan kode etik yang telah menyumpahnya. PGRI (Persatuan Guru Republik Indonesia) merumuskan sejumlah poin kode etik seorang guru di Indonesia sebagai berkut: (1) Guru berbakti membimbing peserta didik untuk membentuk manusia Indonesia seutuhnya yang berjiwa Pancasila. (2) Guru memiliki dan melaksanakan kejujuran professional. (3) Guru berusaha memperoleh informasi tentang peserta didik sebagai bahan melakukan bimbingan dan pembinaan. (4) Guru menciptkan suasana sekolah sebaik-baiknya yang menunjang berhasilnya proses belajar mengajar. (5) Guru memelihara hubungan baik dengan orang tua murid dan masyarakat sekitarnya untuk membina peran serta dan rasa tanggungjawab bersama terhadap pendidikan. (6) Guru secara pribadi dan bersama-sama mengembangkan mutu dan martabat profesinya. (7) Guru memelihara hubungan profess, semangat kekeluargaan dan kesetiakawanan sosial. (8) Guru secara bersama-sama mengembangkan dan meningkatkan mutu organisasi PGRI sebagai sarana perjuangan dan pengabdian. (9) Guru melaksakanakan segala kebijakan pemerintah dalam bidang pendidikan. ${ }^{15}$ Lebih dalam lagi, Harianto GP mengatakan bahwa tujuan pendidikan Kristen mengarahkan peserta didik agar bermoral dan berbudi pekerti kristiani sesuai firman Tuhan dengan menjabarkan visi Allah yang datang ke dunia untuk menyelamatkan manusia dengan cara peserta didik mengenal, mengerti, dan menerima Yesus sebagai Juruselamat pribadi. ${ }^{16}$

Dari uraian tersebut dapat disimpulkan bahwa guru adalah seorang tenaga pendidik

${ }^{14}$ M. Uzer Usman, Strategi Pembelajaran (Jakarta: Erlangga, 2008), 15.

${ }^{15}$ Muhammad Ahyan, Yusuf Sya'bani. Profesi Keguruan: Menjadi Guru yang Religius dan Bermartabat. Ceremedia Communication 44 | Vol. 2 No. 2 (Juli-Desember 2018) profesional yang mendidik, mengajarkan suatu ilmu, membimbing, melatih, memberikan penilaian, serta melakukan evaluasi kepada peserta didik. Guru adalah seseorang yang telah mengabdikan dirinya untuk mengajarkan suatu ilmu, mendidik, mengarahkan, dan melatih muridnya agar memahami ilmu pengetahuan yang diajarkannya tersebut.

\section{Peranan Guru sebagai Interaksi Proses Belajar Mengajar dengan Siswa}

Pembelajaran dikatakan berkualitas apabila pembelajaran melibatkan seluruh komponen utama proses belajar mengajar, yaitu guru, siswa dan interaksi antara keduanya, serta didukung oleh berbagai unsurunsur pembelajaran, yang meliputi: tujuan pembelajaran, pemilihan materi pelajaran, sarana prasarana yang menunjang, situasi dan kondisi belajar yang kondusif, lingkungan belajar yang mendukung kegiatan belajar mengajar, dan evaluasi yang sesuai dengan kurikulum. Prestasi belajar dapat dioptimalkan melalui peningkatan kualitas pembelajaran.

Interaksi adalah komunikasi antara guru dan siswa. Komunikasi tersebut terjadi bersifat dialog atau dua arah yang memiliki efektifitas tinggi dalam proses transmisi informasi. ${ }^{17}$ Transmisi informasi adalah proses belajar mengajar dengan siswa mencakup adalah: (1) Sebagai pengajar, yaitu orang yang mengajarkan suatu ilmu pengetahuan kepada para anak didiknya. (2) Sebagai pendidik, yaitu orang yang mendidikan muridnya agar memiliki tingkah laku yang sesuai dengan norma-norma yang berlaku di masyarakat. (3) Sebagai pembimbing, yaitu orang yang mengarahkan muridnya agar tetap berada pada jalur yang tepat sesuai tujuan pendidikan. (4) Sebagai motivator, yaitu orang yang memberikan motivasi dan semangat kepada muridnya dalam belajar. (5) Sebagai teladan, yaitu orang yang memberikan contoh dan teladan yang baik kepada murid-muridnya. (6) Sebagai administrator, orang yang mencatat

\footnotetext{
${ }^{16}$ Harianto GP, Pendidikan Agama Kristen dalam Alkitab \& Dunia Pendidikan Masa Kini (Yogyakarta: Andi, 2012), 17.

${ }^{17}$ Harianto GP, Komunikasi dalam Pemberitaan Injil (Yogyakarta: Andi, 2012), 155-156.
} 
perkembangan para muridnya. (7) Sebagai evaluator, orang yang melakukan evaluasi terhadap proses belajar anak didiknya. (8) Sebagai inspirator, orang yang menginspirasi para muridnya sehingga memiliki suatu tujuan di masa depan. ${ }^{18}(9)$ mengajar peserta didik, (10) mendidik para murid, (11) melatih peserta didik, (12) membimbing dan mengarahkan, memberikan dorongan pada murid, (14) guru sebagai pemimpin, (15) guru sebagai pelatih, (16) guru sebagai penilai, dan (17) guru sebagai pengarah.

Peranan guru akan senantiasa mengga mbarkan pola tingkah laku dirinya sendiri. Nurlaila mengadakan penelitian sejauhmana peranan Guru Kelas dalam meningkatkan interaksi sosial siswa dalam proses pembelajaran di Sekolah Dasar Negeri 008 Sungai Jalau Kecamatan Kampar Utara, Kabupaten dengan hasil sebagai berikut bahwa cukup maksimalnya peranan guru kelas dalam meningkatkan interaksi sosial siswa dipengaruhi oleh beberapa faktor, yaitu: (1) faktor latar belakang pendidikan guru, (2) faktor pengalaman guru, dan (3) faktor keinginan guru. ${ }^{19}$

Dengan demikian bahwa proses pembelajaran merupakan salah satu unsur yang penting dalam pendidikan yang berkualitas. UNICEP 2000 mengatakan bahwa pendidikan yang berkualitas mencakup 5 unsur, yaitu: (1) Peserta didik yang berkualitas: sehat jasmani dan rohani dan siap untuk berpartisipasi dan belajar, proses belajarnya didukung oleh keluarga dan lingkungannya. (2) Lingkungan belajar yang berkualitas: sehat, aman, protektif dan gender-sensitive, dan menyediakan sumber belajar dan fasilitas belajar yang memadai. (3) Konten yang berkualitas: tercermin dalam kurikulum dan materi ajar

\footnotetext{
${ }^{18} \mathrm{https}: / /$ www.maxmanroe.com/vid/umum/pen gertian-guru.html.

${ }^{19}$ Nurlaila, "Peranan Guru Kels dalam Meningkatkan Interaksi Sosial Siswa dalam Proses Pembelajaran di Sekolah Dasar Negeri 008 Sungai Jalau Kecamatan Kampar Utara, Kabupaten Kampar”. Skripsi (Riau, Pekan Baru: Fakultas Tarbiyah dan Keguruan UIN Sultan Syarif Kasim, 2012).

${ }^{20}$ UNICEF. 2000. Defining Quality in Education. A paper presented by UNICEF at the meeting
}

yang relevan demi tercapainya keterampilan dasar, khususnya di bidang literasi, numerasi dan kecakapan hidup, pengetahuan dalam hal gender, kesehatan, nutrisi, pencegahan HIV/AIDS dan perdamaian. (4) Proses pembelajaran yang berkualitas: guru yang terlatih menggunakan pendekatan pembelajaran yang berpusat pada peserta didik di dalam kelas yang dikelolah dengan baik, penilaian yang baik untuk memfasilitasi belajar dan mengurangi kesenjangan. (4) Outcomes yang berkualitas: lulusan yang memiliki pengetahuan, keterampilan, dan sikap, dan terarah pada pencapaian tujuan pendidikan nasional, serta berpartisipasi positif di dalam masyarakat. ${ }^{20}$

Heick mengatakan bahwa suatu pembelajaran dikatakan aktif, efektif, dan berkualitas bila memiliki karakteristik sebagai berikut: (1) peserta didik aktif bertanya pertanyaan yang baik, (2) pertanyaan dihargai lebih dari jawaban, (3) gagasan atau ide datang dari berbagai sumber, (4) berbagai model pembelajaran digunakan, (5) penilaian dilakukan secara persisten, otentik, transparan, dan tidak bersifat menghukum, (6) kebiasaan belajar (learning habits) terus diterapkan, dan (7) ada kesempatan untuk mempraktekkan pengetahuan. 21 Sedangkan Muhtadi mengemukakan 6 iklim kelas yang kondusif dan berkualitas yaitu: (1) pendekatan belajar yang student-centered, (2) guru menghargai partisipasi aktif dari peserta didik, (3) guru bersikap demokratis, (4) guru mengutamakan dialog dalam mengatasi permasalahan pembelajaran dengan peserta didik, (5) lingkungan kelas yang memotivasi peserta didik untuk belajar dan berpartisipasi dalam kelas, dan (6) berbagai sumber belajar tersedia. $^{22}$

Dari uraian tersebut dapat disimpulkan

of The International Working Group on Education Florence, ItalyJune 2000.

${ }^{21} \mathrm{~T}$. Heick, (2014), The characteristics of a highly effective learning environment. Retrieved May 16, 2017, from http://www.teachthought.com/learning/10characteristics-of-ahighly-effective-learningenvironment/

${ }^{22}$ Muhtadi, Ali. 2005. "Menciptakan Iklim Kelas (Classroom Climate) yang Kondusif dan Berkualitas dalam Proses Pembelajaran". Jurnal Ilmiah Pembelajaran, 1(2).

Excelsis Deo: Jurnal Teologi, Misiologi, dan Pendidikan | 45 
bahwa peranan guru bekerja secara holistik. Guru tidak saja menjalankan tugasnya sebagai seorang pengajar, tetapi menjadi teladan dan teman bergaul bagi para muridnya. Guru adalah tempat diskusi para muridnya dalam menyelesaikan berbagai persoalan yang sedang dihadapinya. Dengan demikian, maka guru dapat membimbing dan melatih murid-murid sesuai dengan bakat dan talenta mereka masingmasing.

\section{Pengelolaan Interaksi Kualitas Proses Belajar-Mengajar terhadap Pengembangan Diri Anak dalam Konteks Minat Belajar}

Penggunaan istilah pengembangan diri dalam kebijakan kurikulum memang relatif baru. Jika menelaah literatur tentang teori-teori psikologi, khususnya psikologi kepribadian, istilah pengembangan diri disini tampaknya dapat disepadankan dengan istilah pengembangan kerpibadian, yang sudah lazim digunakan dan banyak dikenal. Meski sebetulnya istilah diri (self) tidak sepenuhnya identik dengan kepribadian (personality). Istilah diri dalam bahasa psikologi disebut pula sebagai aku, ego atau self yang merupakan salah satu aspek sekaligus inti dari kepribadian, yang di dalamnya segala kepercayaan, sikap, perasaan, dan cita-cita, baik yang disadari ataupun yang tidak disadari. Aku yang disadari oleh individu biasa disebut "conscious mind", sedangkan aku yang tidak disadari disebut "unconscous mind". ${ }^{23}$

Pengembangan diri dalam dunia pendidikan sendiri diartikan sebagai kegiatan pendidikan di luar mata pelajaran sebagai bahan integral dari kurikulum sekolah, sebagai bentuk upayapembentukan watak kepribadian peserta didik melalui kegiatan bimbingan dan konseling serta melalui ekstrakurikuler. ${ }^{24}$

Pengertian pengembangan diri menurut Badan Standar Nilai Pendidikan (BNSP) dan Pusat Kurikulum Badan Penelitian dan

${ }^{23}$ C. George. Boeree, Personality Theories (Yogyakarta: Prismasophie, 2005), 25-36.

${ }^{24}$ Muhaimin, dkk., Strategi Belajar Mengajar (Surabaya: CV Citra Media, 2008), 66.

${ }^{25}$ Allson, Panduan Pengembangan Diri (Jakarta: BSNP dan Pusat Kurikulum, 2006), 8.

${ }^{26}$ Daryanto \& Mulyo Rahardjo, Model Pembelajaran Inovatif, 72.

46 | Vol. 2 No. 2 (Juli-Desember 2018)
Pengembangan Departemen Pendidikan Nasional mengatakan bahwa kegiatan yang bertujuan memberikan kesempatan kepada peserta didik untuk mengembangkan dan mengekspresikan diri sesuai dengan kebutuhan, bakat, minat, setiap konseli sesuai kondisi sekolah dan lingkungan setempat. ${ }^{25}$

Seorang guru wajib meningkatkan kualitasnya interaksi antara guru dengan murid dengan cara terus belajar. Daryanto mengatakan bahwa guru tahu dan sadar bahwa interaksi antara guru dan murid wajib diisi dengan nilai-nilai yang kualitas dengan cara meningkatkan belajar. Ini merupakan pengembangan diri guru dan murid. ${ }^{26}$ Pengembangan diri yang dimaksud adalah pengembangan segala potensi yang ada pada diri sendiri, dalam usaha meningkatkan: potensi berpikir, potensi intelektual, dan potensi skill. ${ }^{27}$ Pengembangan diri adalah suatu proses meningkatkan kemampuan atau potensi, dan keperibadian, serta sossial-emosional seseorang agar terus bertumbuh dan berkembang Pengembangan diri juga berarti dapat dikatakan mengembangkan bakat yang dimiliki, mewujudkan impian-impian, meningkatkan rasa percaya diri, menjadi kuat dalam menghadapi pencobaan, dan menjalani hubungan yang baik dengan sesamanya. Hal ini sebagai upaya anak untuk mendapatkan umpan balik dari orang lain, melatih kepekaan terhadap diri sendiri maupun orang lain, mendalam kesadaran, dan mempercayai usaha hati. $^{28}$

Masalah pengembangan diri para pendidik adalah sangat krusial dalam meningkatkan kualitas proses belajar mengajarnya. Pengembangan diri sangat penting, tidak hanya pada aspek fisik semata seperti peningkatan jenjang pendidikan, banyaknya sertifikat pelatihan, ataupun sertifikat profesi pendidik (bukti pendidik profesional). Akan tetapi pengembangan diri seharusnya juga merambah ranah non fisik

${ }^{27}$ Fanani Abd. Chayyi, Studi tentang Metode Belajar Mahasiswa Pendidikan. Agama Islam dalam Upaya Pengembangan Diri (Fakultas Tarbiyah IAIN, 2003), 4.

${ }^{28}$ Arsis Tarmudji, Pengembangan Diri (Yogyakarta: Liberty, 1989), 7; Utami Munandar, Kreativitas dan Keberbakatan (Jakarta: PT Gramedia. Pustaka Utama, 1999), 15. 
seperti cara pandang, paradigma berpikir, sikap, kebiasaan, profesionalisme maupun perilaku dalam mengajar.

Keadaan ini salah satunya tidak terlepas dari kurang dikembangkannya bahan ajar yang inovatif. Para pendidik padaumumnya hanya menyediakan bahan ajar yang monoton, pokoknya sudah tersedia dan tinggal pakai, serta tidak perlu harus bersusah payah membuatnya. Pada akhirnya, yang menjadi korban adalah peserta didik. Peserta didik akan merasa bosan mengikuti proses pembelajaran yang diselenggarakan guru di sekolah, dan proses pembelajaran menjadi tidak efektif dan efisien. Para guru tampaknya kurang mengembangkan kreativitas mereka untuk merencanakan, menyiapkan dan membuat bahan ajar secara matang yang kaya inovasi sehingga menarik bagi siswanya. Hal ini tentunya menjadi persoalan serius, persoalan yang tidak hanya sekadar bisa dipecahkan dalam tataran wacana semata, namun harus ada aksi nyata guna mengatasi problem tersebut. Salah satunya adalah dengan cara para guru atau pendidik perlu membangun dan menumbuhkan kreativitas dari diri mereka sendiri agar mampu membuat dan mengembangkan bahan ajar yang inovatif.

Dalam proses belajar-mengajar, kondisi kelas yang nyaman akan membantu tersampaikannya materi yang diajarkan oleh guru terhadap peserta didik. Guru dituntut memiliki keterampilan di dalam mengelola komponen-komponen pembelajaran, yang dapat membuat suasana proses belajarmengajar berjalan secara efektif. Guru harus mampu merubah suasana kelas yang dapat membuat siswa menjadi bersemangat dalam mengikuti kegiatan belajar-mengajar. Dengan semangat yang dimiliki, baik dari guru maupun peserta didik, maka interaksi antara guru dan peserta didik dalam proses belajarmengajar dapat berjalan dengan menyenangkan.

Seorang guru harus dapat melakukan pengelolaan kelas sebaik mungkin demi

${ }^{29}$ Rusman, Model-model Pembelajaran: Mengembangkan Profesionalisme Guru (Jakarta: Raja Grafindo Persada, 2014), 271.

${ }^{30}$ Sardiman A.M., Interaksi dan Motivasi Belajar Mengajar (Jakarta: Raja. Grafindo Persada, 2012), 144. tercapainya proses pembelajaran yang nyaman bagi peserta didik. Menurut Rusman bahwa kegiatan guru dalam mengelola kelas meliputi kegiatan pengaturan siswa, pengaturan tempat belajar, pemilihan bentuk kegiatan, pemilihan media pembelajaran, penilaian. Sebagai indikator keberhasilan guru dalam menciptakan kondisi yang memungkinkan dengan melakukan pengelolaan kelas dapat dilihat pada proses belajar mengajar berlangsung secara efektif. ${ }^{29}$

Berkaitan hal tersebut, maka Sardiman memberi solusi cara mengingkatan kualitas interaksi guru dan murid adalah meningkatkan peranan guru dalam kegiatan belajar-mengajar sebagai berikut: (1) informator, (2) organisator, (3) motivator, (4) pengarah, (5) inisiator, (6) transmiter, (7) fasilitator, (8) mediator, dan (9) evaluator. ${ }^{30}$ Arikunto mengatakan guru wajib meningkatkan keterampilam manajerialnya adalah: pengadministrasian, pengaturan dan penataan suatu kegiatan termasuk dalam interaksi antara guru dan muridnya. ${ }^{31}$ Lebih lanjut, Djamarah dan zain menyebut bahwa hal tersebut adalah bahwa guru wajib mampu mengembangkan "manajemen kelas" di mana keterampilan guru untuk menciptakan dan memelihara kondisi belajar yang optimal dan mengembalikannya bila terjadi gangguan dalam proses belajar mengajar. ${ }^{32}$

Peranan guru sangat menentukan keberhasilan interaksi proses belajar mengajar di kelas. Baik buruknya suatu sorang guru dipengaruhi oleh bagaimana ia dapat menyampaikan atau mengajarkan ilmu pengetahuan serta nilai-nilai kehidupan yang mampu membawa peserta didik mewujudkan cita-citanya. Dengan demikian bahwa guru wajib memiliki berbagai kemampuan dan tidak hanya kemampuan akademik yang harus dimiliki oleh seorang guru, tetapi bagaimana seorang guru mempunyai kemampuan untuk memotivasi peserta didik, agar mau belajar yang nantinya akan meningkatkan prestasi serta cita-cita.

\footnotetext{
${ }^{31}$ S. Arikunto, Prosedur Penelitian Suatu Pendekatan Praktik (Jakarta: Rineka Cipta, 2010), 49.

${ }^{32}$ Djamarah \& Zain, Strategi Belajar Mengajar (Jakarta: Rineka Cipta, 2013), 173.
} 


\section{KESIMPULAN}

Dari kajian tentang pengelolaan kualitas proses belajar mengajar terhadap pengembangan diri anak dalam konteks minta belajar dapat disimpulkan sebagai berikut:

Pertama, guru adalah seorang tenaga pendidik profesional yang mendidik, mengajarkan suatu ilmu, membimbing, melatih, memberikan penilaian, serta melakukan evaluasi kepada peserta didik. Guru adalah seseorang yang telah mengabdikan dirinya untuk mengajarkan suatu ilmu, mendidik, mengarahkan, dan melatih muridnya agar memahami ilmu pengetahuan yang diajarkannya tersebut.

Kedua, peranan guru bekerja secara holistik. Guru tidak saja menjalankan tugasnya sebagai seorang pengajar, tetapi menjadi teladan dan teman bergaul bagi para muridnya. Guru adalah tempat diskusi para muridnya dalam menyelesaikan berbagai persoalan yang sedang dihadapinya. Dengan demikian, maka guru dapat membimbing dan melatih murid-murid sesuai dengan bakat dan talenta mereka masing-masing.

Ketiga, guru harus dapat mengelola kelas dengan sangat baik sehingga dalam setiap proses pembelajaran, anak dapat tertarik dan meresponi ketika seorang guru menyampaikan sebuah materi. Dengan itu minat belajar anak dapat termotifasi dan anak dapat mengembakan diri mereka lewat pelajaran yang ia senangi untuk itu seorang guru wajib memiliki kreatifitas yang baik dan punya banyak cara untuk dapat membuat siswanya makin hari makin semngat belajar.

\section{Daftar Pustaka}

"Guru”, KBBI. Offline. Versi 15.1.

A.M., Sardiman. Interaksi dan Motivasi Belajar Mengajar. Jakarta: Raja. Grafindo Persada, 2012.

Ahyan, Muhammad \& Yusuf Sya'bani. Profesi Keguruan: Menjadi Guru yang Religius dan Bermartabat. Ceremedia Communication.
Akadum, "Potret Guru Memasuki Milenium Ketiga. Suara Pembaharuan", http://www.suarapembaharuan.com/N ews/1999/01/220199/ OpEd (Diakses 7 Juni 2008), 1-2.

Allson. Panduan Pengembangan Diri. Jakarta: BSNP dan Pusat Kurikulum, 2006.

Arikunto, S. Prosedur Penelitian Suatu Pendekatan Praktik. Jakarta: Rineka Cipta, 2010.

Atmaka, Dri. Tips Menjadi Guru Kreatif. Bandung: Krama Widya, 2004.

Boeree, C. George. Personality Theories. Yogyakarta: Prismasophie, 2005.

Chayyi, Fanani Abd. Studi tentang Metode Belajar Mahasiswa Pendidikan. Agama Islam dalam Upaya Pengembangan Diri. Fakultas Tarbiyah IAIN, 2003.

Daryanto \& Rahardjo, Mulyo. Model Pembelajaran Inovatif. Yogyakarta: Gava Media, 2012.

Depdiknas. Kamus Besar Bahasa Indonesia. Jakarta: Balai Pustaka, 2005.

Djamarah \& Zain. Strategi Belajar Mengajar. Jakarta: Rineka Cipta, 2013.

GP, Harianto. Pendidikan Agama Kristen dalam Alkitab \& Dunia Pendidikan Masa Kini. Yogyakarta: Andi, 2012.

GP, Harianto. Pendidikan Agama Kristen dalam Alkitab \& Dunia Pendidikan Masa Kini. Yogyakarta: Andi, 2012.

Hamalik, Oemar. Proses Belajar Mengajar. Jakarta: PT. Bumi Aksara, 2003.

Hamid, Moh. Sholeh. Metode Edutainment. Jogjakarta: Diva Press, 2011.

Heick, T. (2014). The characteristics of a highly effective learning environment. Retrieved May 16, 2017, from http://www.teachthought.com/learning /10-characteristics-of-ahighlyeffective-learning-environment/.

https://www.maxmanroe.com/vid/umum/peng ertian-guru.html.

Minarti, Sri. Ilmu Pendidikan Islam: Fakta Teoritis-Filosofis dan AplikatifNormatif. Jakarta: Amzah, 2013.

Muhaimin, dkk. Strategi Belajar Mengajar. Surabaya: CV Citra Media, 2008. 
Muhtadi, Ali. 2005. "Menciptakan Iklim Kelas (Classroom Climate) yang Kondusif dan Berkualitas dalam Proses Pembelajaran". Jurnal

Ilmiah Pembelajaran, 1(2).

Munandar, Utami. Kreativitas dan Keberbakatan. Jakarta: PT Gramedia. Pustaka Utama, 1999.

Nurlaila, "Peranan Guru Kels dalam Meningkatkan Interaksi Sosial Siswa dalam Proses Pembelajaran di Sekolah Dasar Negeri 008 Sungai Jalau Kecamatan Kampar Utara, Kabupaten Kampar". Skripsi. Riau, Pekan Baru: Fakultas Tarbiyah dan Keguruan UIN Sultan Syarif Kasim, 2012.

Rusman. Model-model Pembelajaran: Mengembangkan Profesionalisme Guru. Jakarta: Raja Grafindo Persada, 2014.

Supardi. Kinerja Guru. Jakarta: PT Raja Grafindo Persada, 2014.

Tarmudji, Arsis. Pengembangan Diri. Yogyakarta: Liberty, 1989.

Trianto. Model Pembelajaran Terpadu, Konsep, Strategi dan Implementasinya dalam KTSP. Jakarta: Bumi Aksara, 2010.

UNICEF. 2000. Defining Quality in Education. A paper presented by UNICEF at the meeting of The International Working Group on Education Florence, ItalyJune 2000.

Usman, Ahmad. Studi Pengembangan Metode Pendidikan Professional Tenaga Kependidikan. Bandung: IKIP, 2000.

Usman, Moh. Uzer. Menjadi Guru Profesional. Bandung: Remaja Rosdakarya, 2005.

Usman, M. Uzer. Strategi Pembelajaran. Jakarta: Erlangga, 2008. 